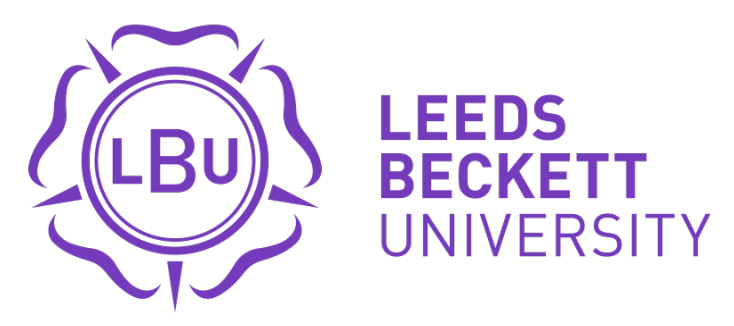

Citation:

Morgan, $J(2020)$ A critique of the Laffer theorem's macro-narrative consequences for corporate tax avoidance from a Global Wealth Chain perspective. Globalizations. pp. 1-21. ISSN 1474-7731 DOI: https://doi.org/10.1080/14747731.2020.1760420

Link to Leeds Beckett Repository record:

https://eprints.leedsbeckett.ac.uk/id/eprint/6746/

Document Version:

Article (Accepted Version)

The aim of the Leeds Beckett Repository is to provide open access to our research, as required by funder policies and permitted by publishers and copyright law.

The Leeds Beckett repository holds a wide range of publications, each of which has been checked for copyright and the relevant embargo period has been applied by the Research Services team.

We operate on a standard take-down policy. If you are the author or publisher of an output and you would like it removed from the repository, please contact us and we will investigate on a case-by-case basis.

Each thesis in the repository has been cleared where necessary by the author for third party copyright. If you would like a thesis to be removed from the repository or believe there is an issue with copyright, please contact us on openaccess@leedsbeckett.ac.uk and we will investigate on a case-by-case basis. 
Professor Jamie Morgan, School of Economics, Analytics and International Business Room-520 The Rose Bowl, Leeds Beckett University Business School j.a.morgan@1eedsbeckett.ac.uk

https://www.tandfonline.com/doi/full/10.1080/14747731.2020.1760420

\section{A critique of the Laffer theorem's macro-narrative consequences for corporate tax avoidance from a Global Wealth Chain perspective ${ }^{1}$}

\section{Introduction}

Austerity politics, economic recession, information leaks, civil society campaigning and critical theory such as financialisation, have provided a broad context and set of concerns that have helped bring discussion and analysis of corporate tax avoidance to the fore. Avoidance is distinguished from evasion. Evasion is the illegal withholding of tax owed, whilst avoidance is the use of strategies that use or exploit opportunities that may be legal (including quasi-legal schemes that have not yet been tested) in order to significantly reduce tax that would otherwise be owed (for nuance see Quentin, 2014). In any case, academics are increasingly familiar with tax secrecy jurisdictions (havens), permanent establishment, beneficial ownership, country-bycountry reporting, commercialisation of sovereignty, the finance curse, transfer pricing and the arm's length principle, and many other concepts and mechanisms that might otherwise be arcane preserves of accountants, tax consultants and a few specialists (e.g. Christensen et al., 2016; Palan, 2002; Palan et al., 2010; Rixen, 2011, 2008; Shaxson, 2011; Sharman, 2010, 2006).

Corporate tax avoidance reduces revenue paid to tax authorities around the world by hundreds of billions of US\$ per year, it promotes cynicism regarding domestic tax regimes, provokes a sense of injustice (one law for the powerful few, another for the many) that undermines democracy, provides a set of lobbying incentives that encourage corporations to subvert or capture democratic spaces, and because of some of the strategies used and locations exploited it serves to facilitate organized crime. It is a complex evolving problem and that problem is not new (see Picciotto, 2011, 1992; Hashimzade \& Epifantseva, 2018; Avi-Yonah, 2007). As Ylönen (2016) points out much of the current critical discussion and analysis is preceded by the work of the United Nations Commission and Centre for Transnational Corporations in the 1970s. This work is mainly absent from the OECD's later framing of the issues with which current critique often engages. ${ }^{2}$ Critique of that framing highlights the conservative continuity of OECD model treaties and methodologies and the limits of the Base Erosion and Profit Shifting or BEPS project, initiated 2013 (e.g. Picciotto, 2016; Apeldoorn, $2019,2018)$. This by no means suggests recent critique is unaware of previous work, but does indicate that there are a whole set of further issues that are important regarding the framing and contestation of ideas - how they are 'positioned' or framed and come to influence the world we live in. ${ }^{3}$ Knowledge and influence for a given field are not free-floating.

The main intent of this paper is to provide critique as a resource for expert-activist counter-discourse. In doing so, however, the purpose is also to add a critical and missing element to the Global Wealth Chain project (Seabrooke \& Wigan 2020a, 2020b). Global Wealth Chain analysis explores the potential for wealth creation to shade into wealth capture, extraction and (questionable) wealth protection through the scope for capital to operate 'multijurisdictionally' to 'hide, obscure and relocate wealth' (Seabrooke \& Wigan 2017: 2, 10-11, \& 2014: 257). This has largely been occupied with case building to identify micro social structures conditioning macro-outcomes (e.g. Sharman, 2017; Bryan, et al., 2017; Seabrooke \& Wigan, 2020a; Morgan, 2020). A missing element has been the undergirding macro- 
narratives that support a status quo and limit political and regulatory action by delimiting what qualifies as legitimate analysis and feasible policy foci. 'Macro-narrative' is a loose term for the concatenation of theory, themes and concepts that are deployed to shape the direction of travel of policy and public understanding. Macro-narratives influence how issues are framed.

In this paper, I argue that the Laffer theorem and its legacy plays a background role in positioning or framing tax avoidance. The original version of the Laffer theorem takes no account of avoidance and its subsequent iterations do so based on incompatible concepts of firm behaviour. These problems are rooted in mainstream economic methodology and distort a more historical, sociological and institutional understanding of the economy. This has additional important consequences for issues of tax justice and fairness, since these sit awkwardly with formal economic analysis. Moreover, the influence of the Laffer theorem extends beyond formal adherence to the theorem. The Laffer theorem is one component in a general direction of travel of policy in the neoliberal age. In context, the Laffer theorem has provided ideational rather than definite empirical support for the principle that we should generally prefer tax rate reductions. It has, through a confused set of claims regarding competition, contributed to a sense that tax avoidance is a signal of inefficiently high tax rates rather than opportunistic behaviour based on the exercise of power. Concomitantly, the Laffer theorem has contributed to the socialisation of citizens, despite that few citizens today could probably put a name to it and despite that economic theory has (to some degree) become more diverse and sophisticated since the theorem was first set out. Following initial discussion of these issues, I argue that the Laffer theorem and its consequences marginalise tax avoidance, even though avoidance remains a recognized issue that attracts negative publicity. Furthermore, this can work in conjunction with the use of data. It is possible to show that corporation tax rates in many countries have trended downwards over recent decades, but that state corporation tax revenues have remained relatively stable. This can give the impression that avoidance is not a major issue, even though such avoidance does occur. Highlighting these issues links Global Wealth Chain analysis to complementary work that explores how advocacy and policy are supported by conditioning 'habituating' 'macro-narratives' (Baker \& Wigan, 2017: 186).

\section{The Laffer theorem}

Perhaps the most relevant, important and enduring mainstream economic theory when considering tax revenue relative to tax rates is the Laffer theorem. A Google search of the term in January 2020 returned 344,000 hits. A Google scholar search produced a result of 19,100 papers with its key term in the title, abstract or main body. ${ }^{4}$ This included works by such prominent figures as Lawrence Summers, Patrick Minford, Jeffrey Sachs and Paul Krugman (for range see Strulik \& Trimborn, 2012; Trabandt \& Uhlig, 2011; Laffer, 1981; Canto et al., 1981; Blinder, 1981). The Laffer theorem postulates that total tax collected (the tax yield) is influenced by the tax rate because the tax rate itself can affect economic activity. The original version is based on a simple intuition regarding the incentive and disincentive effects of the tax rate..$^{5}$ As the tax rate is increased there may be a trade-off with, depending on the focus of the tax, entrepreneurship, hours worked, productivity and output or some other measurable 'effort' mechanism. Logically, this measurable effect means that there will be some point at which a further increase in the tax rate could cause the tax yield to fall and that there is a point just before this where the tax rate maximises the tax yield. This is standardly sketched as the Laffer curve and versions of this are common. For example, the Wikipedia site illustrates the curve with: ${ }^{6}$ 


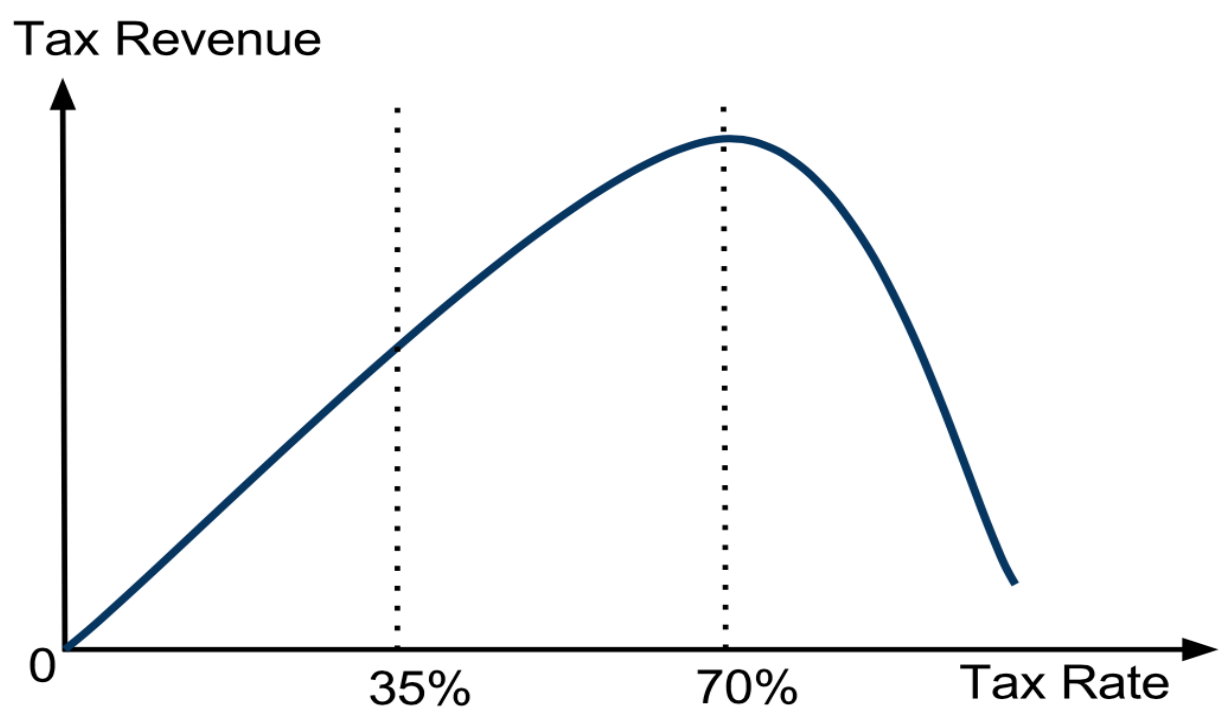

To be clear, the Laffer theorem does not commit an economist to the proposition that lowering the tax rate increases the tax yield. This is ostensibly an empirical issue that depends on whether one is to the left or right of an optimum tax rate, which the theory suggests maximises the tax yield. What the Laffer theorem does suggest is that there is a given optimum rate. However, the Laffer theorem was developed in the mid-1970s in the USA and proved immediately attractive to the new right whose advocates were developing a confluence of ideational positions that would later be labelled neoliberalism. As such, it converged with a whole series of claims being made based on George Stigler, Milton Friedman and others' new-variant 'neoclassical' Chicago School tenets and some components of Hayekian thought. Mirowski and Plehwe's (2009) edited work on the Mont Pelerin society is often used as a touchstone for the general aims and tenor of this work as both an academic and political project (for examples of evolving context see also, Lavery, 2018; Hay, 2004; Blyth, 2002).

Though the Laffer theorem does not commit an economist to the proposition that lowering the tax rate increases the tax yield, the theorem does provide ideational support for the plausibility of increasing the tax yield by reducing the tax rate. In the 1970s, at a time of generally high tax rates on income from wages and capital, this provided an opening. This is made clear in two papers (though that is not the primary purpose of the papers), both of which discuss the theorem's origin and influence; a roughly contemporaneous article by Jude Wanniski (then an associate editor of The Wall Street Journal, Wanniski, 1978a), and later Arthur Laffer's (2004) retrospective paper, published by the US conservative think tank, the Heritage Foundation (which returned 524 citations January 2020, 84 more than a previous search conducted in November 2018). Wanniski recounts a meeting in a Washington DC restaurant in 1974 between himself, Laffer, Donald Rumsfeld (Chief of Staff of President Ford at that time) and Dick Cheney (Rumsfeld's deputy and a former classmate of Laffer at Yale). During a conversation about President Ford's tax policy, Laffer sketched his curve and explained its rationale. ${ }^{7}$ The idea then began to disseminate through right wing conservative policy circles, the press and academia (see also Laffer \& Seymour, 1979). Famously, the Laffer theorem provided the ideational logic for significant cuts to top rate income tax in the 1980s in both the UK under Margaret Thatcher and USA under Ronald Reagan, and arguments to reduce all other forms of tax, including corporation tax started to gain prominence (see Cooper, 2012). ${ }^{8}$ Historically, this period represented the high tide of monetarism and early supply-side economics and much has changed since then, but the point worth stressing is that a direction of travel, a context of socialisation for attitudes towards taxation, had been set in motion. 


\section{The political and social significance of the Laffer theorem}

In the period after World War II until the 1970s the dominant ideational context of taxation complemented a broadly Keynesian and social democracy point of view. This varied across the major capitalist countries, but broadly involved the idea that paying tax was an important prosocial act of participation, which signalled a collective commitment to society. The state collected taxes on income and these taxes were significantly progressive (higher percentages for greater earnings). ${ }^{9}$ The state then engaged in a combination of redistribution, welfare spending, and investment in social and economic infrastructure and other services. Crucially, it was presupposed that the state had a significant broad based role to play in society and the economy and thus had a legitimate right to tax extensively. It is worth noting here that the according to Knapp's (1924) longstanding state theory of money and according to the more recent Modern Monetary Theory (MMT, see Fullbrook \& Morgan, 2020) the current consensus on the role played by tax may be false. There may be a misunderstanding of the causal role and significance of tax if a state is a sovereign currency issuer (rather than merely currency user), in which case it first spends money into existence and then taxes for other purposes (to add legitimacy to the money of account, to reduce inequality and to manage inflation, but not as a necessary source and thus prerequisite of spending). This, however, is not the main point for our purposes. The point is that the Laffer theorem was an important part of an ideational position that challenged the dominant ideational context. The dominant context sought to represent tax as an important and positive act of commitment to social cohesion within a narrative of collective socio-economic progress (a society that placed limits on inequality etc.).

Whilst the positive representation of taxation has not been eradicated, the Laffer theorem provided the basis for a very different way of positioning taxation. ${ }^{10}$ The Laffer theorem focuses on individualised incentive effects. It provides an easily understood rationale for why it is possible to reduce tax rates and increase yields: people are incentivised to increase their effort, more economic activity occurs, the economy grows, and there is more income from wages and capital from which tax revenue can be collected. ${ }^{11}$ This subtly shifts the way both the state and tax are implicitly conceived. If lowering taxes is an incentive and higher taxes are a disincentive, then the implication is that in general tax is negative - a necessary evil to be minimised. This, in turn, sits comfortably with the idea that tax is an expropriation of earned income. And, this, in turn, sits comfortably with the idea that wealth is primarily generated outside the state's sphere of active operation and the state cannot be trusted to make good use of that income. To be clear, none of these associated ideas necessarily follow, but they should be immediately recognizable to any reader as part of a convergent set of claims in the neoliberal age (see also Seabrooke \& Wigan, 2020b; Baker \& Wigan, 2017; Murphy, 2015): developing over the years into the idea of the minimal state whose primary functions beyond security are to provide legal context for and a facilitating regulation of competitive markets and to correct market failures; a situation where the state itself is run according to market principles of efficiency (combining privatisations with new public management theory, public-private initiatives etc.).

It is also worth bearing in mind that there is something subconsciously appealing about the focus on incentive and this partly explains the expedience of the Laffer theorem for the right and its potential attractiveness to electorates. It speaks directly to the conservative right's longstanding rugged individualist narrative, but its appeal extends further, since it translates what might otherwise seem an inner selfishness into a positive trait: psychologically it suggests we are all intrinsically primed to be economically successful and the only thing preventing that is the 'dead hand' of the state. ${ }^{12}$ The Laffer theorem thus facilitates self-interested ways of thinking, it encourages us to think in a transactional and individualistic mode, it focuses on what is essentially striving and assumes as background that an economy and society are places 
of competition. The overall impression conveyed, however, is positively posed: dynamic wealth creation (contrasted with the negative of taxation).

The Laffer theorem has clearly provided a key ideational resource that has helped to embed the idea that lower taxes are to be preferred to higher and this has become part of the common sense of the neoliberal age - a legacy effect. There is, however, an additional important consequence here. The Laffer theorem suggests that, in principle, everyone gains if lower taxes free us and economic activity increases. Yet, if significant tax reductions are implemented then these reductions can quite easily disproportionately benefit the wealthy and this can be to an even greater extent if the tax system was previously highly progressive. As such, the theorem has played a background role in socialising electorates to accept policies that can lead to growing inequality. It provides one strand in an 'everyone gains' logic and this has been basic to the 'trickle down' economics that have dominated in the last forty years. Growing income and wealth inequality, of course, have been observed in many countries over the last forty years and the World Inequality Database makes this clear. Moreover, it seems unlikely to be coincidence that inequality has manifested to the greatest degree in those countries, beginning with the USA and UK, that have most enthusiastically adopted the general stance with which the Laffer theorem has been politically associated (since lower tax rates across tax bands ('flatter' systems) asymmetrically increase retained income, and affect ownership of assets from which rents accrue, and this is exacerbated through the simple compounding mechanisms set out by Thomas Piketty — which by no means requires one to accept that Piketty provides an adequate explanation of capitalism; for comment see Fullbrook \& Morgan, 2014; Morgan, 2015). ${ }^{13}$

\section{Absence of evidence but not of authority}

So, the Laffer theorem has provided a key ideational resource that has helped to embed the idea that lower taxes are to be preferred to higher. To be clear, however, this has not been an evidence based position. Almost all attempts to model the Laffer theorem and apply it to real economies have found that actual tax rates are to the left of the Laffer curve turning point that would yield maximum revenue (most prominently Trabandt \& Uhlig, 2011; for contrast see Creedy \& Gemmell, 2017). ${ }^{14}$ Moreover, historically many of the more prominent tax rate reductions that have been based on some version of the Laffer theorem's incentive argument have resulted in higher government budget deficits. During the Reagan administration, for example, USA national debt grew from just less than $\$ 1$ trillion to almost $\$ 3$ trillion. Increased deficits are clearly problematic, since the incentive logic suggests that lower tax rates increase economic activity with a view to increasing the tax yield, which would imply, assuming appropriate planning, either no change to subsequent budget deficits or an actual reduction. ${ }^{15}$ Of course, there are limits to this criticism, since one cannot definitely know how an economy would have fared without the tax cut (one can only model possible scenarios) and there are many reasons why subsequent government spending may increase faster than anticipated. However, in the USA case, whenever tax rate cuts are proposed the Congressional Budget Office attempts to model the likely consequences for revenue against projected spending. In almost every major case since Reagan they have found that proposed tax rate reductions were likely to increase the deficit because projected revenue would be adversely affected. Prominent economic commentators in the USA, such as Paul Krugman, have consistently pointed this out and the conclusion drawn is typically that a policy of reducing tax rates (notably top tax rates) is implemented despite the evidence (see Berman \& Milanes-Reyes 2013). ${ }^{16}$

The latest example is provided by President Trump's Tax Cuts and Jobs Act 2017. The Act proposed wide ranging tax rate cuts and provoked immediate criticism based on the disproportionate gains to top income earners and the likely increase in budget deficits over the 
next decade. ${ }^{17}$ The Trump administration resolutely stuck to the line that tax cuts followed an incentive-effort logic and that this would be good for the economy. In June 2019 President Trump awarded Laffer the Presidential Medal of Freedom. Though egregious and in some ways extreme the Trump example illustrates just how blatantly politicised the argument has been and just how little evidence can sometimes matter. ${ }^{18}$ Moreover, it is also worth bearing in mind that subsequent empirical failure of a policy can also create additional opportunities to advance a compatible political agenda. If future tax revenues do not meet previous claims and deficits increase, then governments that adopt a neoliberal stance can simply flip to a focus on the need for cuts to government spending - targeting welfare and service spending - and this remains compatible with a conservative ideology of self-reliance and the minimal state (a state which, despite creating the problem it is then responding to, makes the claim that it is merely applying necessary principles of prudent fiscal discipline - according to widely accepted 'good household management' analogies). So, in context Laffer theorem-influenced argumentation can become part of what Jamie Peck and his various collaborators refer to as the 'failing forward' of neoliberalism (e.g. Brenner et al., 2010). The Trump administration, for example, began to use rising budget deficit arguments to support proposed cuts to Medicaid and Medicare in 2019.

There is an important distinction that needs making here. Politicised knowledge may not depend on evidence - at least in the sense of a track record that establishes policy definitely results in the claimed general effects - but knowledge can only be put to political purpose, becoming an effective source of socialisation or a justification for policy, if it carries authority in some sense.

\section{Mainstream economics, status and the significance of macro-narratives for Global Wealth Chain work}

The attraction of the Laffer theorem in a political context has not just been its simple intuition that economic activity may be influenced by the tax rate, but rather the status of that claim when expressed in a formal economic construct and when stated by an economist. Mainstream economics claims to be the social science that most closely matches the characteristics of the natural sciences. It defines its subject matter in terms of quantitatively assessed aspects of society (a core of transactional activity mediated by money - finance, investment, production, trade, employment etc.). It thus has a great deal of quantitative data from which patterns can be, in principle, observed and theories of behaviour inferred. For mainstream economists, the implication (developed over the decades) is that study of the economy is conducive to formal mathematical expression and to the application of models of social action to particular economic contexts. Mainstream economics has thus become increasingly technical and has acquired status as something akin to physics and engineering for distinctly 'economic' social action. ${ }^{19}$ Clearly, this can be extremely attractive for policymakers, since any technically posable claim, set out in a format that has the discursive markers of science, provides a veneer of legitimacy for a preferred policy stance. Just as clearly, this status effect can continue to operate even if a theory is controversial and evidence is, at the least, disputed - odd though that seems. Here, one might note that dispute can actually work to the advantage of policy advocacy, depending on the historical context. The Laffer theorem was first introduced at a time of severe economic problems in the UK and USA and so offered a 'new' perspective from a then relatively obscure economist at a time when Keynesian economics was under pressure. Its appeal illustrates an odd tension: mainstream economics acquires much of its authority from its status as the most scientific of the social sciences and yet theory is clearly not neutral despite the traditional positive-normative divide that economics has maintained. Berman and MilanesReyes (2013) make much this point in terms of the politicisation of the Laffer theorem in the 
USA and Berman later builds on this, drawing on the influential work of Marion Fourcade and her various collaborators to suggest that:

First, economists are most likely to be influential advisers in situations understood as technical, and in ill-defined situations where uncertainty forces policymakers to look for new solutions. Second, the indirect influence of economics on policymaking is likely as important as the direct role of economists. The spread of economic discourse reshapes how non-economist policymakers understand a given issue. The spread of economists' technical tools determines the information available to policymakers and changes the process of decision-making. Third, meso-level social orders affect the political influence of economics. Economists' actions in the political field must be understood in light of the dynamics of the semi-autonomous, globalizing professional field. (Hirschman \& Berman, 2014: 780)

It is here that connections can be made between 'habituating' 'macro-narratives' and the Laffer theorem in the context of Global Wealth Chains. Global Wealth Chain analysis explores how wealth can be hidden, obscured and relocated (Seabrooke \& Wigan, 2020a, 2020b). Specific practices, however, are enabled by ideas and this enablement can occur in many ways. In some cases, macro-narratives can be pinned down or readily identified; Baker and Wigan's (2017) initial work on lobby groups and policy influence (e.g. the CityUK), illustrates this. One might also draw attention to complementary work undertaken on epistemic arbitrage - the process by which professionals seek to circumscribe a field of expertise and construct that field as the source of authoritative discussion of a given problem or issue (Seabrooke, 2014; Seabrooke \& Henrikson, 2017). Here, the very possibility of arbitrage indicates some contestation of groupings and organizational venues and a degree of diversity, where networks of relations, gaps, uncertainties and the potentials for shifts, creating new strategic advantages, can be explored.

However, the effects of theory are not restricted to lobby groups and the arrogations of expert-activists that organise to propagate ideas. Hirschman and Berman (2014), building on the work of Fourcade and various collaborators emphasise that knowledge becomes part of and in turn works back on social order. As such, theory can provide an important strand in 'macronarratives' and these are no less important to the possibility of Global Wealth Chains than are specific practices. Clearly, one of the Laffer theorem's attractions has been its mainstream economic formulation and the status this provides in a policy context; not just in spite of, but in some ways because of the dispute and controversy that it has created. In general, theory can provide credibility, status, and plausibility when policymakers seek reasons to do something, it can operate as part of broader socialisations and it can place emphasis on some issues and not on others. Theory, too, can hide and obscure. In order to highlight this, I now turn to methodological critique of the Laffer theorem and begin to focus more specifically on corporate tax avoidance. The Laffer theorem as a formal economic construct marginalises (renders peripheral) corporate tax avoidance in various ways.

\section{A methodological critique of the Laffer theorem's mainstream economic form}

Global Wealth Chain and complementary work emphasises that corporate tax avoidance is achieved through the exercise of power based on opportunity and has become part of the ordinary practice of modern capitalism (see Seabrooke \& Wigan, 2020b; Finér \& Ylönen, 2017; Ylönen \& Teivainen, 2018; Morgan, 2017, 2016a). 'Offshore' tax havens and tax secrecy jurisdictions are not just localities used by a few unscrupulous firms, groups and individuals, rather they are intrinsic to contemporary financial practice; they are part of a system whose 
rules and practices begin in the main financial centres of the world and are maintained by the 'Big Four' accountancy firms, banks and by revolving door relations with captured states whose concerns and foci ultimately work against the public interest (see also Aalbers, 2017; Wainwright, 2011; Corporate Reform Collective, 2014).$^{20}$ However, the original formulation and initial applications of the Laffer theorem do not focus on corporate tax avoidance. As such, the issue is immediately marginalised, but it is also rendered problematic in terms of methodology.

The Laffer theorem translates the proposition that the tax rate affects economic activity, with its simple intuition that there is an incentive-effort mechanism, into a formal mathematical statement. The mathematics are based on Rolle's theorem, which states that any real-valued continuous function to which differential calculus can be applied will have a stationary point i.e. a first derivative whose gradient is zero, if the function has equal values at two points and a defined interval between those two points (see Blinder, 1981; Canto et al., 1981; Bender, 1984). Laffer simply assumes that the tax yield varies from 0 at a tax rate of $0 \%$ through a set of positive values and back to 0 if the tax rate is $100 \%$ (because no one would engage in taxable economic activity) and this creates the necessary two points of equal value and an interval between them. Based on Rolle's theorem, tax revenue follows a defined pathway expressed in the function, reaching a maximum at the stationary or turning point. George Stigler referred to the theorem as 'tautology' (Berman \& Milanes-Reyes, 2013) and in an early response, Alan Blinder (influential Professor of Economics at Princeton and later member of President Clinton's Council of Economic Advisors and vice-chairman of the Board of Governors of the Federal Reserve System in the USA) notes that the theorem is formalisation, a 'mathematical result' and not an economic finding (Blinder, 1981: 83). This, however, is not irrelevant, since formalisation conforms to the expectations of mainstream economics. It provides disciplinary legitimacy. Blinder's subsequent comments confirm this in so far as Blinder restricts his critique to suggesting that it seems unlikely that income and corporation tax rates in the USA are to the right of optimum. There are, however, more fundamental methodological issues (see also Mirowski, 1982).

As economic theory, the Laffer theorem develops a series of economic models or applications. All involve versions of standard economic concepts: well defined marginal rates, elasticities and substitutions for given factors and a tractable theoretical framework that allows equilibrium solutions. Economic behaviour is stated as a set of responses, where for the purposes of the model the tax rate acts as the dominant signal, inducing those responses. Behaviour, for example, becomes a factor supply response defined in the relevant function (such as an adapted Cobb-Douglas production function). The aim is to derive a tax revenue schedule that demonstrates the existence of a Laffer curve. Within economics much of the critique of these models has focused on the various problems of supply-side economics, but the underlying problem is more basic, affecting mainstream economics in general. The predicates of theory and the modelling process are unrealistic.

Real 'agents' engage in economic activity within societies and economic activity is a subset of social activity. This has context based on continually evolving culture, conventions institutions etc. Real agents are socialised, but they are not socially determined in any strict sense. They may follow routines or habits but they also reflect, learn and adapt. As such behaviour is always relational, it may be goal-directed, it may be relatively consistent for some period, but it is also diverse, contingent and evolving. Mainstream economic theory and models, however, have traditionally provided a quite different representation. In mainstream economic theory, the point is usually to demonstrate a tractable solution to a problem based on some concept, such as equilibrium. The solution typically requires a simplified closed system with manageably few (from a mathematical point of view i.e. the number of equations to solve) interacting components. Finding a solution requires those interacting components to follow 
simple well-defined consistent behaviours. The simplest of all consistent behaviours to define quantitatively are primitive goal maximisations. Axioms provide this consistency in economic theory and in empirical models this is translated into constants for any given 'variable of interest' (such as a fixed coefficient defining a marginal rate of substitution). In order to expedite solutions, it is also typical to assume away any complex interdependency between components, since this can complicate mathematical solutions, leading to multiple solutions or no solution. As such, behaviour is typically expressed as a set of well-defined, universal, and separated or independent relations that follow a fixed whenever $\mathrm{x}$ then $\mathrm{y}$ form.

So, mainstream economics reduces behaviour to a set of atomistic and regular relations. This is deeply unrealistic, but mainstream economics remains committed to tractability since much of its scientific status is derived from its claim to be the most mathematical of the social sciences. In terms of realist 'ontological' critique it is scientistic rather than scientific, and yet remains powerful and socially significant (for critique and alternatives see Lawson, 2019, 2015; Morgan, 2016b; Morgan \& Patomäki, 2017b). ${ }^{21}$ The Laffer theorem and its applications share the basic problems of lack of realism. In the case of the Laffer theorem one clear mathematical or technical problem is that expressing tax behaviour in a function that can be sketched as a curve assumes that the economic agent's response to tax rate changes is the same irrespective of the direction of travel along the curve. The function defines a fixed rate of change and the economic agent's quantified response to that change will result in the same determinant tax yield irrespective of whether the tax rate is an increase or a decrease to that point on the curve, irrespective of whether the tax rate change is an isolated one or one of several, and irrespective of whether the changes are all in the same direction (a trend) or skip back and forth. But to any real thinking agent these would be experienced and reflected upon quite differently.

This technical problem reveals a more basic problem of theory and application: the roles of both socialisation and politics are obscured. The Laffer theorem may well have provided a useful theory for policy purposes, but the theorem itself cannot adequately incorporate learned behaviour, where economic agent's observations of policy consistency or responsiveness to persuasive policy argument makes a difference to how they respond to tax rate changes. Given the broader socialising effects that the incentive-effort argument has had (embedding preferences for the principle of lower taxes), this is ironic. But it is also suggestive, since this lack of contingent response to how tax arguments are made (whilst tacitly being a form of argument for how taxation should be thought about) highlights how normative issues sit awkwardly with the requirements of formal economic analysis. This is a basic weakness of the Laffer theorem's macro-narrative role that Global Wealth Chain analysts should be aware of. More specifically, in the case of the Laffer theorem there has been a basic tension when trying to reconcile applications of the theorem to corporate tax avoidance and this in turn has important implications for issues of tax justice and fairness.

\section{The incentive-effort mechanism and the incentive to avoid corporation tax}

As noted, Global Wealth Chain and complementary work emphasise that corporate tax avoidance is achieved through the exercise of power based on opportunity. Whilst early versions of the Laffer theorem do not focus on corporate tax avoidance, more recent applications have attempted to integrate it (for an informed discussion see Papp \& Takáts, 2008). The integration focuses on observed differences between effective and statutory tax rates; i.e. the difference between what the corporation really pays and what it would pay if it paid the statutory headline rate. Significant difference is taken to constitute a signal that tax rates are too high and this provides an incentive to avoid corporation tax. ${ }^{22}$ The implication is that states respond by lowering tax rates to reduce this incentive, creating a convergence 
between statutory and effective tax rates. This, in turn, becomes a component in the derivation of the optimum rate for the Laffer curve. There is a basic inconsistency here.

Introducing avoidance creates a tension between two different meaning frames for the idea of incentive: incentive-effort as a social mechanism and the incentive to avoid tax as a potentially anti-social one. This undermines the coherence of a modelled single optimum rate for maximum revenue, even if one were to accept the tenets of the Laffer theorem. The original framing of the theorem suggested that tax rates could become a disincentive to economic activity - a disincentive to working more and working harder, to innovating and investing etc. Though one can criticise the methodology involved, it remains the case that the original Laffer concept had its own positive narrative based on a contrast. The Laffer theorem implies taxation is a negative involving expropriation of earned income. The implicit assumption is that wealth and income are in fact earned and are in some practical and ethical sense deserved.$^{23}$ This sits comfortably with a primary focus on dynamic wealth creation - even if it invites critique based on consequences for inequality. ${ }^{24}$ However, avoidance behaviour sits awkwardly with this. Avoidance implies the possibility that wealth is being captured and then protected from the legitimate right of the state to tax. Moreover, if the state reduces corporation tax rates because of avoidance, then it could be argued the state is rewarding those who cheat the system. The counter would be that the corporation has provided a legitimate signal that tax rates are too high.

However, there is no reason to think that avoidance is motivated by legitimate grievance regarding corporation tax rates - or indeed that it ought to be the firm who decides what that legitimate rate is. The overwhelming evidence suggests that avoidance is a response to opportunity based on exploitable characteristics of tax systems. The firm is exercising power not making a clear and public evidential case regarding the injustice of punitive taxation - quite the reverse, firms often rely on practices which maximise privacy, and on deliberate and obfuscating complexity, secrecy, and lobbying. When challenged, firms do not respond with ethical argument (since it would do reputational damage to address the ethical case by suggesting avoidance is ethically 'good') or with claims that taxes are too high; firms typically respond with a bland statement that we pay all legally required taxes; this shifts responsibility and obfuscates, since avoidance is intentional activity. Tax avoidance is deliberate exploitation of potentials or weaknesses in domestic tax law and in the international system of tax laws, a situation that lobby groups actively seek to perpetuate (through resistance to fundamental structural change).

The important point to make here is that incorporating avoidance into applications of the Laffer theorem assimilates an ethically contestable behaviour as though it were simply another 'economic' variable. This is deeply problematic. It is, however, significant from a Global Wealth Chain perspective in multiple ways. Methodologically, the Laffer theorem follows a standard mainstream economic format. Applications of the Laffer theorem encourage a format that focuses on stripped-down tests matching a model, a hypothesis and a conceptual form. The economist is represented as a problem-solving data analyst and corporation tax becomes a technical issue of revenue collection. The firm becomes a modelled economic agent, responding in an instrumental calculative domain. This obscures the potentials for wealth capture and depoliticises a profoundly political issue. The result is another strand in the peripheralisation of corporate tax avoidance. This does not prevent corporate tax avoidance being a matter of political or public concern; it does not prevent public outrage, but it does create a disciplinary haven for avoidance behaviour because the whole issue of ethics sit awkwardly with the way economics approaches the problem.

Again, consider the broader socialising effects that may embed (and this transcends formal awareness and advocacy of the Laffer theorem); if tax is expropriation of (deserved) earned income, then the relation between the taxer and the tax payer, i.e. the state and the firm 
(or any other tax payer), is intrinsically antagonistic and this antagonism sits awkwardly with any positive sense of the state's role in producing and reproducing society and the economy (for counter argument see Mazzucato, 2018, 2015). This is readily recognizable in contemporary society; the neoliberal age has fostered a meta-value that the state should be reluctant to tax, and so politicians start to express this point of view, but this simply reinforces popular scepticism and undermines positive narratives regarding the right to tax and distorts any socialised duty to pay. The case for taxation thus becomes less general and more specific - governments across the political spectrum have responded by particularising the case for public spending, leading to more defensive discourses (given that there is an assumption that taxes pay for spending on services etc.), and one consequence of this has been a focus on hypothecated taxes (to address urgent issues like social care in aging societies). What this lacks is a focus on how the construction of the state and the moral or ethical case for fair and just taxation can be primary issues, which could provide a very different set of attitudes and practices in regard of tax behaviour (see Murphy, 2015).

\section{The problem to be solved?}

It is also important to note that if the state responds to avoidance by reducing tax rates, then it is not compelling or encouraging more ethical behaviour by the firm. The capacity to engage in avoidance has not been denied to the firm nor has the tendency to engage in avoidance been socialised away. The firm may continue to pursue avoidance to some degree and a return to avoidance remains an implied threat. Moreover, there is a further inconsistency here. For tax avoidance to constitute a legitimate signal that tax rates are too high, then for the purposes of consistency from a mainstream economic perspective the current rate must be inefficient. In mainstream economic theory, the exercise of power is a market distortion. Economic efficiency requires Pareto conditions and perfect competition to apply, whilst avoidance strategies typically require firms to have multiple incorporations, and most multi-national enterprises (MNEs) have scale and exploit market segmentation. For an efficiency claim to make sense, therefore, there must be some kind of structural pathway inducing a turn to efficiency by the firm. No pathway currently exists. In any case, there is no reason to assume real firms have an interest in the mainstream concept of economic efficiency, since this is quite different than maximising profit if profit can be increased by retaining more income (protecting it from taxation) via avoidance strategies. Power is about what is effective not what is efficient and real firms influence their environment if they can. There seems little basis to expect real behaviours to converge on 'efficiency' in the current system.

Moreover, it seems naïve to expect that there is an easily identified satisfactory corporation tax rate at which avoidance ceases if firms feel no compunction to respect the spirit of the law and opportunities for tax avoidance continue to arise. As such, the integration of avoidance into applications of the Laffer theorem indicates a power asymmetry is tacitly presupposed, and if not challenged, perpetuated. More generally, the problem of avoidance is not being solved in any obvious sense if rates are reduced. The term compliance is often used in tax discourse, but its meaning seems perverse when avoidance is incorporated into standard economic theory, such as Laffer applications. If tax rates are lowered to reduce avoidance, then it is the state that is ultimately compliant based on the exercise of power by the firm.

There are several main data sources that estimate the extent of corporate tax avoidance and Gabriel Zucman is perhaps the best-known person currently working on the subject in political economy. According to recent estimates from Zucman and his colleagues (Tørsløv et al., 2018; also Zucman, 2016; Saez \& Zucman, 2019), six main European tax havens are used to artificially shift $€ 350$ billion in reported MNE revenues per year, and this extends to $€ 600$ billion on a global basis. The EU alone is deprived of around $€ 60$ billion a year in tax revenue 
and the UK of around $€ 13$ billion, and the latter may be a conservative estimate if contrasted with Richard Murphy's estimate of at least $£ 20$ billion within a general evasion-avoidance tax gap of around $£ 120$ billion in the UK (Murphy, 2014). So, avoidance continues and this is despite growing criticism of avoidance practices and despite the OECD BEPs project and many well-meaning and constructive initiatives, such as country-by-country reporting. This seems to suggest that issues like commercialisation of sovereignty, adverse tax competition between states (attracting reporting of income through actions that beggar other states) and arbitrage behaviour by firms, remain more relevant to the world we live in (for context see Christensen and Shaxson, 2016; Palan et al., 2010; Palan, 2002) than are mainstream economic concepts of 'competitively efficient tax regimes'. Zucman makes an important point here:

Why are corporate tax rates falling? The standard explanation is that globalization makes countries compete harder for productive capital, pushing corporate tax rates down. By cutting their rates... countries can attract more machines, plant and equipment, which makes workers more productive and boosts their wage... Is this view of globalization and of the striking tax policy changes of the last years well founded empirically? Our simple answer is "no". Machines don't move to low-tax places, paper profits do... [T]ax avoidance and the failure to curb it are the main reason why corporate tax rates are falling globally... (Tørsløv et al, 2018: 1)

Zucman's point in referring to 'striking policy changes' is that policy developments have not prevented avoidance and that the theory of competition in which avoidance continues to occur obfuscates regarding this. However, there is a final point regarding the potential misuse of data here that is worth highlighting. At core, policy change has included a general trend reduction in corporation tax rates in many countries. However, state corporation tax revenues have remained relatively stable and are typically a small percentage of total taxation. This can give the impression that avoidance is not a major issue even though avoidance continues to occur. This also has obfuscation effects that can be usefully challenged.

\section{Trends in corporation tax rates}

Since the early 1980s, statutory rates of corporation tax within the G7, the European Union and OECD in general have trended downwards. One can see this trend replicated across a range of illustrative countries: ${ }^{25}$

Table 1

\begin{tabular}{|l|l|l|l|l|l|}
\hline \multirow{2}{*}{ Selected states } & \multicolumn{5}{|c|}{ Statutory Corporate Tax Rate (\%) } \\
\cline { 2 - 6 } & $\mathbf{1 9 8 2}$ & $\mathbf{1 9 9 2}$ & $\mathbf{2 0 0 2}$ & $\mathbf{2 0 1 2}$ & $\mathbf{2 0 1 8}$ \\
\hline Germany & 60 & 40.5 & 38.3 & 29.6 & 29.8 \\
\hline France & 50 & 34 & 35.4 & 36.1 & 34.4 \\
\hline Sweden & 57.8 & 30 & 28 & 26.3 & 22 \\
\hline Netherlands & 48 & 35 & 34.5 & 25 & 25 \\
\hline Slovakia & $*$ & $*$ & 25 & 19 & 21 \\
\hline Poland & $*$ & 40 & 28 & 19 & 19 \\
\hline Ireland & 50 & 40 & 16 & 12.5 & 12.5 \\
\hline UK & 52 & 33 & 30 & 24 & 19 \\
\hline USA & 49.7 & 38.9 & 39.3 & 39.1 & 25.8 \\
\hline $\begin{array}{l}\text { OECD } \text { unweighted } \\
\text { average }\end{array}$ & 48 & 38.1 & 30.5 & 25.4 & 24.1 \\
\hline
\end{tabular}


It is clear from Table 1 that the statutory rate has reduced on average from around $50 \%$ to less than $25 \%$. There is some degree of variation in the timing and proportionality of reductions, but significant reductions have occurred in all cases. These include countries that have stayed closer to the social democratic tradition, relatively new members of the EU and those more closely identified as champions of 'neoliberalism', such as the UK. The most recent high profile reduction occurred in the USA in the form of President Trump's Tax Cuts and Jobs Act 2017, and the apparent laggard status of this might seem anomalous if one were unfamiliar with the US tax system and its place in the international tax system (see Palan \& Wigan, 2014). Still, in general, rates can be observed to have halved over three and a half decades.

Corporation tax is a tax on profits, so one would expect to see fluctuations in its metrics. However, this is different than general levels and trends in proportionality. In terms of levels, personal income, social security and consumption taxes tend to be far greater proportions of total tax revenue than corporation tax revenue and corporation tax revenue is typically a small proportion of total tax revenue. If we draw on OECD Revenue Statistics 2017 (which provides retrospective data) and replicate the countries in Table 1 as Table $2:^{26}$

Table 2

\begin{tabular}{|l|l|l|l|l|l|l|l|}
\hline \multirow{2}{*}{ Selected states } & \multicolumn{6}{|c|}{ Tax revenue as a \% of total tax revenue 2015 } \\
\cline { 2 - 8 } & $\begin{array}{l}\text { Personal } \\
\text { income } \\
\text { tax }\end{array}$ & $\begin{array}{l}\text { Corporate } \\
\text { income } \\
\text { tax }\end{array}$ & $\begin{array}{l}\text { Social } \\
\text { security }\end{array}$ & $\begin{array}{l}\text { Property } \\
\text { tax }\end{array}$ & VAT & $\begin{array}{l}\text { Other } \\
\text { consumption }\end{array}$ & Other \\
\hline Germany & 26.5 & 4.7 & 37.6 & 2.9 & 18.8 & 9.0 & 0.5 \\
\hline France & 18.9 & 4.6 & 37.1 & 9.0 & 15.3 & 9.1 & 6.1 \\
\hline Sweden & 29.1 & 6.9 & 22.4 & 2.4 & 20.9 & 7.2 & 11.1 \\
\hline Netherlands & 20.5 & 7.2 & 37.8 & 3.8 & 17.6 & 7.9 & 0.3 \\
\hline Slovakia & 9.7 & 11.5 & 42.7 & 1.3 & 21.3 & 12.4 & 1.1 \\
\hline Poland & 14.4 & 5.7 & 38.5 & 4.2 & 21.6 & 14.4 & 1.3 \\
\hline Ireland & 31.6 & 11.3 & 16.8 & 6.4 & 19.7 & 12.9 & 1.2 \\
\hline UK & 27.7 & 7.5 & 18.7 & 12.6 & 21.2 & 11.7 & 0.5 \\
\hline USA & 40.5 & 8.5 & 23.7 & 10.3 & 0.0 & 17.0 & 0.0 \\
\hline $\begin{array}{l}\text { OECD } \\
\text { unweighted } \\
\text { average }\end{array}$ & 24.4 & 8.9 & 25.8 & 5.8 & 20.0 & 12.4 & 2.7 \\
\hline
\end{tabular}

Corporation tax revenue is typically less than $10 \%$ of total tax revenue and the OECD average was $9 \%$ in 2016. Furthermore, this is not new. The OECD site provides data from 1965 to 2016 and over that period the OECD average for corporation tax revenue varied between $7.2 \%$ and $11.2 \%$, but in 26 of 52 years it fluctuated between $8 \%$ and $9 \%$ and only exceeded $10 \%$ in the 4-year run up to the global financial crisis. ${ }^{27}$ As a concomitant to its relatively small contribution to total tax revenues, corporation tax revenue has also tended to be a relatively small proportion of GDP. Between 1965 and 2016, the OECD average varied between 2.02\% and $3.62 \%$ of GDP, but only exceeded $3 \%$ in 6 of 52 years, again focused around the run-up to the global financial crisis.

Clearly then, whilst corporation tax rates have reduced markedly over the decades, corporation tax revenue has remained a relatively small proportion of total tax revenue and GDP, and both measures have fluctuated within quite narrow bands. This is so on average but is also replicated for individual countries (albeit with greater variability). There is scope, therefore, to claim that lowering corporation tax rates has not resulted in marked declines in 
revenue and that by extension avoidance is not a major issue. Moreover, given that corporation tax is a relatively small proportion of total tax revenue, there is scope to argue that there are more important issues to address. However, such claims would be a misuse of the data and several counter-arguments can be made.

Simply noting the trend takes no account of the growth in number of business entities available to pay tax and takes no account of any difference in tax behaviour between different entities. It is not, in fact, an argument about whether entities are paying tax, it is a reductive empirical claim that obfuscates regarding this. Richard Murphy, for example, makes this point in the UK case (Murphy, 2014, 2015, 2017). There has been a significant growth in the number of corporate entities in the UK and digitilisation has reduced the costs and difficulty of incorporation. Privatisation and then financialisation have provided context. According to the UK government register (Companies House, 2018), there were 3.77 million entities in the UK as of March 2018, after allowing for ongoing liquidations and this was 3 million more than in $1979 .{ }^{28}$

Intuitively one would expect that more entities would mean a growth in tax revenues. That is, unless the proportion and value of the economy accounted for by corporations reduced and perhaps the number of large corporate entities earning significant revenues likewise tailed off. In fact, the reverse of these is the case. Of course, in the UK, as in most OECD states, corporation tax rates have fallen. What does this suggest? Well, it creates a problem for policy if based on the original Laffer theorem, since the reasonable inference is that the tax rate is already to the left of optimum (which is by no means an endorsement of the idea of a given optimum). Moreover, some of the trend growth in incorporations has observably been part of strategic behaviour to avoid tax and this has in fact been mainly a strategy pursued by larger companies - essentially MNEs. As Murphy noted as early as 2014, tax receipts from large companies fell in the UK by an average $£ 150$ million a year over a previous twelve-year period. Zucman and his colleagues work confirms this general picture, as an international problem, as does the work of many contributors to the Tax Justice Network. A firm can create a chain of incorporations where one corporation can be a legal person that owns another. Large firms can act differently based on expert advice; they can exploit the opportunity to report in different jurisdictions.

It should be clear then, that corporate tax avoidance is a major issue. Contemporary levels of corporation tax revenue do not provide reasons to consider avoidance unimportant. They are in part a consequence of avoidance. Moreover, if placed in the context of trend increases in profit share relative to wage share over the period of neoliberalism, then there is surely a general systemic capacity to pay more corporation tax and not less. This applies even if one is an advocate of variants of Modern Monetary Theory, since the purpose of taxation can be to reduce inequality and socialise pro-social behaviour. It might seem odd, therefore, that there is not greater pressure to raise corporation tax rates as well as improve collection (the Labour party in the UK, for example, placed great emphasis on this in their 2017 and 2019 election manifestos and received significant pushback; Morgan, 2019a). This is an important reminder of the role of macro-narratives. Problems of avoidance are endemic. This needs to be highlighted empirically and conceptually and this begins with critique of theory that does otherwise. Data does not just speak for itself, evidence can be used and misused. A focus on the aggregated data can obfuscate regarding whether and how given entities are paying tax. Moreover, data does not directly address whether entities should pay tax. It says nothing regarding the right to tax and the duty to pay, and as we have already suggested these are important issues that can become peripheral rather than central.

\section{Conclusion}


In this paper I have focused on the role of the Laffer theorem in order to explore several ways in which theory can influence the problem of taxation. The main intent has been to provide critique as a resource for expert-activist counter-discourse and to raise awareness of the issues. It should be clear that theory provides an important element in conditioning a world in which Global Wealth Chain practices can flourish. Critique, however, is just one small facet of opposition. It provides for clarity where obfuscation occurs. It provides a resource for advocacy and creates grounds for alternatives. Advocacy and alternatives, meanwhile, are ongoing issues. What should also be clear is that there is a need for a combination of fundamental structural change to deny opportunities to firms to engage in avoidance and a transformative change to the socialisation of firms and of society regarding the role of the state and taxation. This is just one issue among many that contemporary capitalism must address in the wake of Covid-19 (e.g. Gills, 2020; Gills \& Morgan, 2019; Morgan, 2019b).

The best current corporation tax alternative is regional or global unitary taxation by formula apportionment. Unitary taxation consolidates the accounts of the whole firm and treats its separate corporate entities as a single entity for tax purposes. Taxable income or profit is allocated to individual countries based on a measure of real economic presence and this makes manipulating where income or profit is reported superfluous. The policy also reduces the potential for adverse tax competition and there is already momentum for a version of unitary taxation within the European Union (the Common Consolidated Corporate Tax Base and its current transitional form the $\mathrm{CCTB}$ ). Unitary taxation provides for fundamental structural change that denies opportunities to firms to engage in avoidance. However, this does not eliminate the motive to engage in avoidance. This is a more sociologically amorphous issue, which requires a transformative change to the socialisation of firms and of society, including our habituating macro-narratives. This is not about naively asking firms to be nice, explicit ethical commitments and justification should be statutory requirements of corporate practice and collective sanction should apply, such that it pays to be good - again the European Union already has weak initiatives tending this way. Concomitantly, given the status and power of economics, positive change requires a reorientation of economic theorisation - a more socially realistic economics of institutions and processes in which normative claims play a central role. The economy is not some inviolable separate technical sphere. It is an expression of what we value and how we live and in any genuinely rational society this is a matter for collective deliberation and agreement, not obfuscation. Argument can involve technical aspects, but should not fall foul of technocratic capture or spurious precision in quantification. There is scope for change.

\section{References}

Aalbers, M. (2017). Geographies of tax. Progress in Human Geography, 42(6), 916-927.

Apeldoorn, L. (2019). Exploitation, international taxation and global justice. Review of Social Economy, 77(2), 163-183.

Apeldoorn, L. (2018). BEPS, tax sovereignty and global justice. Critical Review of International Social and Political Philosophy, 21(4), 478-499.

Avi-Yonah, R. (2007). International Tax as International Law: An analysis of the international tax regime. Cambridge: Cambridge University Press.

Baker, A. \& Wigan, D. (2017). Constructing and contesting City of London power: NGOs and the emergence of noisier financial politics. Economy and Society, 46(2), 185-210.

Bender, B. (1984). A analysis of the Laffer curve. Economic Inquiry, 22(3), 414-420.

Berman, E. \& Milanes-Reyes, L. (2013). The politicization of knowledge claims: The "Laffer Curve" in the US Congress. Qualitative Sociology, 36, 53-79. 
Blinder, A. (1981). Some thoughts on the Laffer curve. pp. 81-92 in Meyer L. (editor) Supply-Side Effects of Economic Policy Economic Policy Conference series St. Louis: Federal Reserve Bank of St. Louis.

Blyth, M. (2002). Great Transformations. Cambridge: Cambridge University Press.

Brenner, N. Peck, J. \& Theodore, N. (2010). After neoliberalization? Globalizations, 7(3), 327-345.

Bryan, D. Rafferty, M. \& Wigan, D. (2017). Capital unchained: finance, intangible assets and the double life of capital in the offshore world. Review of International Political Economy, 24(1), 56-86.

Canto, V. Joines, D. \& Laffer, A. (1981). Tax rates, factor employment and market production. pp. 332 in Meyer L. (editor) Supply-Side Effects of Economic Policy Economic Policy Conference series St. Louis: Federal Reserve Bank of St. Louis.

Christensen, J., Shaxson, N., \& Wigan, D. (2016). The finance curse: Britain and the world economy. British Journal of Politics and International Relations, 18(1), 255-269.

Christensen, J. \& Shaxson, N. (2016). Tax competitiveness - a dangerous obsession. in Pogge, T. and Mehta, K. (editors) Global Tax Fairness Oxford: Oxford University Press.

Companies House (2018, June) Companies Register Activities 2017 and 2018. London: HM Government.

Cooper, J. (2012). Margaret Thatcher and Ronald Reagan. Basingstoke: Palgrave Macmillan.

Corporate Reform Collective (2014). Fighting Corporate Abuse: Beyond Predatory Capitalism. London: Pluto.

Creedy, J. \& Gemmell, N. (2017). Measuring revenue-maximizing elasticities of taxable income: Evidence for the US income tax. Public Finance Review, 45(2), 174-204.

Dietsch, P. \& Rixen, T. (editors) (2016). Global Tax Governance: What is wrong with it and how to fix it. Colchester: ECPR Press.

Eskelinen, T. \& Ylönen, M. (2018). Panama and the WTO: New constitutionalism of trade policy and global tax governance. Review of International Political Economy, 24(4), 629-656.

Finér, L. \& Ylönen, M. (2017). Tax-driven wealth chains: A multiple case study of tax avoidance in the Finnish mining sector. Critical Perspectives in Accounting, 48, 53-81.

Fullbrook, E. \& Morgan, J. (editors) (2020) Modern Monetary Theory and its Critics. London: World Economics Association Books.

Fullbrook, E. \& Morgan, J. (editors) (2014). Piketty's capital in the twenty-first century. London: World Economic Association Books and College Publications.

Fullerton, D. (2008). Laffer curve. pp. 283-305 in Durlauf, S. and Blume, L. (2008) The New Palgrave Dictionary of Economics. Basingstoke: Palgrave Macmillan, second edition.

Gills, B. (2020). Deep Restoration: From the Great Implosion to the Great Restoration. Globalizations, online first.

Gills, B. \& Morgan J. (2019). Global Climate Emergency: after COP24, climate science, urgency and the threat to humanity. Globalizations, online first.

Gutiérrez, D. \& Melguizo Á. (2012). What Drives Tax Morale. OECD Development Centre Working Paper 315, Paris: OECD.

Hashimzade, N. \& Epifantseva, Y. (editors) (2018). The Routledge Companion to Tax Avoidance Research. London: Routledge.

Hay, C. (2004). The normalising role of rationalist assumptions in the institutional embedding of neoliberalism. Economy and Society, 33(4), 500-527.

Hirschman D. \& Berman, E. (2014). Do economists make policies? On the political effects of economics. Socio-Economic Review, 12(4), 779-811.

Knapp, G. F. (1924). The State Theory of Money. London: Macmillan.

Laffer, A. (2004) The Laffer curve: Past, present and future. The Heritage Foundation Backgrounder, Report number 1765.

Laffer, A. (1981). Government exactions and revenue deficiencies. Cato Journal, 1: 1-21.

Laffer, A. \& Seymour, J. (1979). The Economics of the Tax Revolt. New York: Harcourt Brace.

Lavery, S. (2018). The legitimation of post-crisis capitalism in the United Kingdom: Real wage decline, finance-led growth and the state. New Political Economy, 23(1): 27-45.

Lawson, T. (2019). The Nature of Social Reality: Issues in Social Ontology. London: Routledge.

Lawson, T. (2015). The Nature and State of Modern Economics. London: Routledge. 
Mazzucato, M. (2018). The Value of Everything: Making and Taking in the Global Economy. London: Allen Lane.

Mazzucato, M. (2015). The Entrepreneurial State: Debunking Public vs Private Sector Myths. London: Anthem, revised edition.

Mirowski, P. \& Plehwe D. (editors) (2009). The Road From Mont Pelerin. Harvard: Harvard University Press.

Mirowski, P. (1982). What's wrong with the Laffer curve? Journal of Economic Issues, 16(3), 81528.

Morgan, J. (2020). The firm: Private equity finance and global wealth chain effects. in Seabrooke, L. and Wigan, D. (editors) Global Wealth Chains: Governing Assets in the World Economy Oxford: Oxford University Press, forthcoming.

Morgan, J. (2019a). The Left and an economy for the many not the few. pp. 94-137 in Scott, D. (editor) (2019) Manifestos, Policies and Practices: An Equalities Agenda. London: Trentham Press/UCL IOE Press.

Morgan, J. (2019b). Will we work in twenty-first century capitalism? A critique of the fourth industrial revolution literature. Economy and Society, 48(3), 371-398.

Morgan, J. (2017). Taxing the powerful, the rise of populism and the crisis in Europe: The case for the EU Common Consolidated Corporate Tax Base. International Politics, 54(5), 533-551.

Morgan, J. (2016a). Corporation tax as a problem of MNC organizational circuits: The case for unitary taxation. British Journal of Politics and International Relations, 18(2), 463-481.

Morgan, J. (2016b). The contemporary relevance of a Cambridge tradition: Economics as political economy, political economy as social theory and ethical theory. Cambridge Journal of Economics, 40(2), 663-700.

Morgan, J. (2015). Piketty's calibration economics: Inequality and the dissolution of solutions? Globalizations, 12(5), 803-823.

Morgan, J. \& Patomäki, H. (editors) (2017a). Brexit and the Political Economy of Fragmentation: Things fall apart. London: Routledge.

Morgan, J. \& Patomäki, H. (2017b). Contrast explanation in economics: its context, meaning, and potential. Cambridge Journal of Economics, 41(5), 1391-1418.

Morgan, J. \& Sun, W. (2017). Corporations, taxation and responsibility: practical and onto-analytical issues for morphogensis and eudaimonia - A posse ad esse? pp. 185-210 in M. Archer (editor) Morphogenesis and Human Flourishing. London: Springer.

Morgan, J. \& Sheehan, B. (2015). The Concept of Trust and the Political Economy of John Maynard Keynes, illustrated using central bank Forward Guidance and the democratic dilemma in Europe. Review of Social Economy, 73(1), 113-137.

Murphy, R. (2017). 'There is no Laffer effect in UK corporation tax: in fact the reverse is true', Tax Research UK, July $25^{\text {th }}$, available at: http://www.taxresearch.org.uk/Blog/2017/07/25/thereis-no-laffer-effect-in-uk-corporation-tax/

Murphy, R. (2015). The Joy of Tax. London: Bantam Press.

Murphy, R. (2014). The tax gap £119.4bn. London: Public and Commercial Services Union.

OECD (2017). Revenue Statistics in 2017: Tax Revenue Trends in the OECD. Paris: OECD.

Palan, R. (2002). Tax havens and the commercialization of state sovereignty. International Organization, 56(1), 151-76.

Palan, R. \& Wigan, D. (2014). Herding cats and taming tax havens: The US strategy of 'not in my backyard'. Global Policy, 5(3), 334-343.

Palan, R. Murphy, R. \& Chavagneux, C. (2010). Tax havens. New York: Cornell University Press.

Papp, T. \& Takáts, E. (2008) Tax rate cuts and tax compliance: The Laffer curve revisited. IMF Working Paper WP/08/7.

Patomäki, H. (2009). How to tell better stories about the history and future of Global Political Economy. Review of International Political Economy, 16(2), 309-320.

Picciotto, S. (2016). Taxing multinational enterprises as unitary firms. ICTD Working Paper 53.

Picciotto, S. (2011). Regulating global corporate capitalism. Cambridge: Cambridge University Press.

Picciotto, S. (1992). International business taxation. London: Weidenfeld and Nicolson. 
Quentin, D. (2014). Risk-mining the public exchequer: Reflecting the realities of tax risk in the theory of tax avoidance. http://www.davidquentin.co.uk/Risk-Mining_The Public Exchequer.pdf.

Rixen, T. (2011). From double tax avoidance to tax competition: explaining the institutional trajectory of international tax governance. Review of International Political Economy, 18(2), 197-227.

Rixen, T. (2008). The Political Economy of International Tax Governance: Transformation of the State. Basingstoke: Palgrave Macmillan.

Saez, E. \& Zucman, G. (2019). The Triumph of Injustice. London: Norton \& Company.

Seabrooke, L. (2014). Epistemic arbitrage: Transnational professional knowledge in action. Journal of Professions and Organization, 1(1), 49-64.

Seabrooke, L. \& Henrikson, L. (editors) (2017). Transnational Networks in Transnational Governance. Cambridge: Cambridge University Press.

Seabrooke, L. \& Wigan, D. (editors) (2020a). Global Wealth Chains: Governing Assets in the World Economy. Oxford: Oxford University Press, forthcoming.

Seabrooke, L. \& Wigan, D. (2020b). Global tax battles: the fight to govern corporate and elite wealth. Oxford: Oxford University Press.

Seabrooke, L. \& Wigan, D. (2017). The governance of global wealth chains. Review of International Political Economy, 24(1), 1-29.

Seabrooke, L. \& Wigan, D. (2015a). Powering ideas through expertise: Professionals in global tax battles. Journal of European Public Policy, 23(3), 357-374.

Seabrooke, L. \& Wigan, D. (2015b). How activists use benchmarks: reformist and revolutionary benchmarks for global economic justice. Review of International Studies, 41(5), 887-904.

Seabrooke, L. \& Wigan, D. (2014). Global wealth chains in the international political economy. Review of International Political Economy, 21(1), 257-263.

Sharman, J. (2017). Illicit global wealth chains after the financial crisis: micro states and an unusual suspect. Review of International Political Economy, 24(1), 30-55.

Sharman, J. (2010). Offshore and the new international political economy. Review of International Political Economy, 17(1), 1-19.

Sharman, J. (2006). Havens in a Storm: The Struggle for Global Tax Regulation. New York: Cornell University Press.

Shaxson, N. (2011). Treasure Islands: Uncovering the damage of offshore banking and tax havens. Basingstoke: Palgrave Macmillan.

Strulik, H. \& Trimborn, T. (2012). Laffer strikes again: Dynamic scoring of capital taxes. European Economic Review, 56(6), 1180-1199.

Tørsløv, T. Wier, L. \& Zucman, G. (2018). The missing profits of nations. working paper, June; available: http://gabriel-zucman.eu/files/TWZ2018.pdf

Trabandt, M. \& Uhlig, H. (2011). The Laffer curve revisited. Journal of Monetary Economics, 58(4), 305-327.

Wanniski, J. (1978a). Taxes, revenue and the "Laffer Curve". The Public Interest, 50, 3-16.

Wanniski, J. (1978b [1998]). The Way the World Works. Washington DC: Regnery Publishing.

Wainwright, T. (2011). Tax doesn't have to be taxing: London's onshore finance industry and the fiscal spaces of a global industry. Environment and Planning A: Economy and Space, 43(6), 1287-1304.

Ylönen, M. (2016). Back from oblivion? The rise and fall of the early initiatives against corporate tax avoidance from the 1960s to the 1980s. Transnational Corporations Journal, 23(3), 33-65.

Ylönen, M. (2017). Policy diffusion within international organizations: A bottom-up analysis of International Monetary Fund tax work in Panama, Seychelles, and the Netherlands. WIDER Working Paper 2017/157.

Ylönen, M. \& Teivainen, T. (2018). Politics of intra-firm trade: Corporate price planning and the double role of the arm's length principle. New Political Economy, 23(4), 441-457.

Zucman, G. (2016). The Hidden Wealth of Nations: The Scourge of Tax Havens. Chicago: University of Chicago Press.

\footnotetext{
${ }^{1}$ Thanks to Barry Gills for provision of materials and four anonymous reviewers for insightful comment.
} 

${ }^{2}$ To be clear, the focus is limits and critique is not unequivocal, the OECD is responsible for hosting various positive initiatives.
The OECD Harmful Tax Competition: An Emerging Global Issue report of 1998 is commonly considered the main signpost
that signals contemporary concern with tax avoidance, and it is this that Ylönen notes lacks significant reference to the work
of the UN Centre for Transnational Corporations (and the UN CTC had an initial more politicised focus on the power of
multinational enterprises, whilst the OECD became more focused on economic efficiency, transaction costs, corporate social
responsibility/governance and human rights). One might also highlight the more recent Global Forum on Transparency and
Exchange of Information for Tax Purposes, which has produced a series of "Peer Review" reports. Moreover, it is possible to
also compare and contrast the OECD with the role of other significant organizations, such as the IMF, whilst also considering their mutual influence (see Ylönen, 2017: 16).

${ }^{3}$ Seabrooke and Wigan tend to draw on constructivism, original institutionalism (Commons, Veblen) and Bourdieu (fields, habitus, structure as structuring etc) to explore networks. Concomitantly, Ylönen (2016) is concerned with the consequences for the collective memory of the field through knowledge transmission. Rixen, by contrast appropriates more standard economic concepts and terminology (rationalist explanations of collective action problems leading to asymmetric prisoner's dilemmas that produce undesirable outcomes - rule stretching that perpetuates problematic situations - but where his concern is with how to overcome the deep-seated problems commonly identified in the critical literature and which Seabrooke and Wigan also share a concern with, see Rixen, 2011 and also Dietsch \& Rixen, 2016). In general, there is quite a wide latitude in terms of how the contingency and openness of social reality is theorised in economics, IPE and in social theory and philosophy (e.g. Patomäki, 2009; Lawson, 2012; Morgan \& Sheehan, 2015; Morgan \& Patomäki, 2017b).

${ }^{4}$ The figure has no doubt increased:

https://scholar.google.co.uk/scholar?hl=en\&as sdt=0\%2C5\&q=laffer+curve\&oq=Laff

${ }^{5}$ Note, this intuition is not original to Arthur Laffer - versions of it have been attributed to David Hume, Adam Smith and many others. Laffer provides a mainstream economics version with a formal mathematical statement, though this too has antecedents in the nineteenth century.

${ }^{6} \mathrm{See}$. https://en.wikipedia.org/wiki/Laffer curve Note: this is an asymmetric version of the Laffer Curve, mathematically this is not the only possibility.

${ }^{7}$ The exact details of the meeting are disputed and some elements are referred to later as apocryphal. Wanniski died in 2005 and the napkin the curve was supposedly sketched on was placed in the Smithsonian, but Laffer notes he was not consulted prior to this and does not recall sketching the curve on a napkin. The New York Times felt this worth commenting on in a 2017 editorial (in the context of Speaker of the House Paul Ryan invoking Laffer to support Trump on tax). If anything, this highlights the powerful narrative role the 'event' has played; see also Wanniski's (1978b [1998]) monograph.

${ }^{8}$ To be clear, there is far more subtlety and contingency to the historical role that the Laffer theorem has played in given times and places than can be set out here. For example, some conservative right governments who have treated the theorem as useful have remained skeptical regarding its capacity for real insight. There is a difference between suggesting the Laffer theorem facilitates lowering tax rates and claiming that a Laffer theorem model is appropriate as a way to set tax rates to ensure realistic future government budget planning. Both Geoffrey Howe when at the UK Treasury and George Bush Sr. as President in the USA were less convinced of the latter. See subsequent section on deficits.

${ }^{9}$ Re progressive taxation, there are of course differences between systems for income tax on individuals which target wages, those which target other broader earnings (such as capital gains) and those which target a corporation's income (taxable profits).

${ }^{10}$ This is not to suggest critique of taxation was new; the Laffer theorem provided an opportunity to articulate critique and to frame the issues quite differently.

${ }^{11}$ This shares some of the reasoning of a Keynesian multiplier, but is very different in context and use.

12 This is underpinned by critique that suggests the state suffers from bureaucratization, adverse self-interest of administrators and systems and corruption, and that it encourages dependencies that harm even when they are conceived as help or support. Shrinking the state reduces these potentials (see Deirdre McCloskey's recent Bourgeois Era trilogy).

${ }^{13}$ Given that the rate of increase in income and wealth inequality varies between countries this increase cannot be attributed in any simple sense to "Globalization" - domestic policy must play a role (attitudes to the role of the state, progressive taxation and "predistribution" and redistribution etc.).

${ }^{14}$ See also Fullerton (2008) who identifies taxable income with respect to after tax share as a core metric and surveys the optimal tax rates calculated in a range of prior studies and finds the mid-range elasticity in those studies to be 0.4 and the typical revenue maximizing tax rate to be $70 \%$.

${ }^{15}$ Assuming a standard contemporary mainstream economic perspective.

${ }^{16}$ To be clear controversy and criticism of the Laffer theorem from within economics (and one could as readily note trenchant critique from Robert Solow or James Tobin) are not what is of interest. It is the broader socialising effects of the individualized incentive-effort focus at the heart of the theorem and the periodic partisan use of the theorem because it is expressed in mainstream economic format that are of interest.

${ }^{17}$ See for example, responses to Trump's tax cuts at: http://www.igmchicago.org/surveys/laffer-curve

${ }^{18}$ In any case, if and when benefits from tax cuts unequally accrue, they are likely to do so to higher income and older sections of the population (who are liable to have more assets), i.e. those most likely to vote and most likely to vote along more conservative lines. Lower corporation tax, for example, leads to higher EBITDA profits which can then lead to higher dividend payments to shareholders or stock buybacks which increase equity prices, both of which increase returns to owners of assets. 19 Though mainstream economics has also increasingly applied its concepts and methods to all branches of social life (commonly referred to as economics imperialism - identified by George Stigler, pursued archetypally by Gary Becker, critiqued by Ben Fine and Dimitris Milonakis).

${ }^{20}$ See, for example, Oswald, M. (Director) (2017) The Spider's Web: Britain's Second Empire http://spiderswebfilm.com According to the OECD, a tax haven typically exhibits: limited to no information exchange to other jurisdictions (limited 
cooperation or compliance), lack of transparency, an offshore market that is separated from the domestic economy and no or low effective tax rates. However, many of the world's main economies and centers of finance could be described as tax havens in so far as they provide specialist services with tax consequences. These extend to various forms of secrecy (represented in the Tax Justice Network financial secrecy index).

${ }^{21}$ This is not to suggest there has been no innovation in mainstream economics over the decades; but rather that innovations are limited by the overwhelming focus on tractability and this continually undermines the degree of fundamental change: axioms are loosened, sub-optimality defined, disequilibrium and path-dependent, cultural or conventionally informed evolutions explored.

${ }^{22}$ Formally, convergence takes account of where the transaction costs of avoidance are exceeded by the gains from avoidance.

${ }^{23}$ As such the theorem downplays luck, privilege, Weberian life chances and the role of the state in providing Berlin's positive freedoms or liberties.

${ }^{24}$ This does not imply inequality is justified, it is merely to acknowledge the internal consistency of the claim, which can then be challenged based on empirical and normative grounds.

${ }^{25}$ Data available from (plus archive): https://stats.oecd.org/index.aspx?DataSetCode=Table_II1

For an account of the derivations see http://www.oecd.org/ctp/tax-policy/corporate-and-capital-income-tax-explanatoryannex.pdf Note: Ireland joined the EU in 1973, Slovakia and Poland in 2004.

${ }^{26}$ Data available from (OECD, 2017: 3) and: http://oe.cd/oecd-revenue-statistics

Note, averages conceal significant variance in terms of the distribution, particularly if considering total taxation rather than only corporate. The OECD average fluctuates today around 33-35\% of GDP, but the range over time has extended from around $10 \%$ in 1965 (Turkey) to 46\% in 2015 (Sweden and Denmark). Some convergence has occurred as automatic stabilisers and welfare systems have spread beyond Europe and the US since 1965 (and despite 'neoliberalism').

${ }^{27}$ Figures available: https://data.oecd.org/tax/tax-on-corporate-profits.htm

${ }^{28}$ According to the 2017 statistical release; since $2004,96 \%$ of all registered entities have been private limited companies, and in combination these and limited liability partnerships and limited partnerships account for $99 \%$ of the total register. There may be historically more public limited corporations but these are in turn a smaller constituent within the total number of registered entities. There were 11,291 overseas corporate bodies 'with a physical presence in the UK' ( $22 \%$ from the USA). 